\title{
Losing the plot: the geological anti-narrative
}

\section{Adelene Buckland}

In 1850 the prominent Cambridge geologist Adam Sedgwick thundered against the theory of the transmutation of species, put forward in the anonymously-published 'sensation' Vestiges of the Natural History of Creation, as a 'physical romance, and a work of imagination'. His complaint was not just that the theory was not 'true'. It was that, in arguing that the universe and its species had progressed through an ascending scale, in which each part of the series had been derived 'from that which went before it', development gave the world a form not unlike the forms of 'romance'. The 'narrative' of Vestiges had 'at least the symmetry and external form of a true history', Sedgwick wrote, 'But, after all', its language was 'no better than a downright cheat'. 'Sedgwick's damnation of a bad geological theory as fiction masquerading as the truth was not unusual. In 1827 the geologist Charles Lyell wrote of the Lamarckian theory of the transmutation of species, from which the author of Vestiges had borrowed, that it had 'delighted' him 'more than any novel' he 'ever read, and much in the same way, for they address themselves to the imagination'. ${ }^{2}$ It had long been commonplace to denigrate scientific works or theories by associating them with a broadly-defined notion of 'romance' as a merely imaginative discourse not sufficiently rooted in empirical fact. But in the case of the transmutation of species the argument worked especially well because it drew on formal similarities between the continuous plots of 'romance' novels widely pilloried in the press for having drawn susceptible young and female readers into their snare, and the developmental continuities of evolutionary theories. It drew too on similarities in pricing, format, and the publishers shared by radical evolutionary tracts and cheap, salacious fictions. This essay, developed from Sedgwick's suspicion of the close formal relationship between thrilling and romantic 'novels' and evolutionary theories, will chart the ways in which geologists, arguing about the form and structure of the earth in the early nineteenth century, were also always arguing about the literary forms and structures by which the earth's features might be better understood.

Lyell and Sedgwick used the terms 'novel' and 'romance' almost interchangeably, as was common in the literary culture of the day: as Michael McKeon notes, "romance" served as an all-purpose generic touchstone for the 
negative definition of an emergent form whose positive denomination - "the novel" - remained unstable even at the end of the eighteenth century'. ${ }^{3}$ Novels, from Don Quixote to the writings of Aphra Behn, Daniel Defoe, Samuel Richardson and Henry Fielding, for instance, had claimed that they were literally 'true' by eschewing 'romance', and the convention of denigrating romantic fictions persisted into the nineteenth century as novelists in a self-consciously 'realist' tradition claimed their work to be authoritative, truthful (if not actually true) and serious. ${ }^{4}$ Geologists, attempting to make their own claims to cultural authority, wisely chose the same enemy.

As the most determined of all geologists of his generation to keep the excesses of story out of science, Sedgwick offers an important test case here. Sedgwick was not a fan of the 'romance' or of the women and youths who were deemed to be most susceptible to its charms, to the extent that he was suspicious of all forms of fiction. He pretended never to read even the novels of his favourite authors, Defoe and Scott, unless he was sick (though he was sick suspiciously often). ${ }^{5}$ And he counselled his geological colleagues to write in a style that was plain and nontechnical but was nonetheless poorly constructed, in order to keep novelreaders at bay. ${ }^{6}$ For Sedgwick, keen reader of the Edinburgh Review, the novel was a suspect genre, written by women and read by the idle. As several critics have discussed, the heavyweight quarterlies frequently displayed an anxiety that prose fiction coiled readers into its rhythms and structures, making it impossible to think straight until the end of the story. Images of women neglecting their domestic duties, too absorbed in fiction, or of 'fast' young gentlemen failing to live up to their responsibilities, too susceptible to novel-reading and to ephemeral fashions, were widespread. For men of science like Sedgwick the self-determining forms of fiction presented a double worry: in the first place, novel-reading might tempt readers away from hard scientific work, so that potential men of science wasted their lives on merely literary pursuits, perhaps reading geological works from their armchairs but rarely venturing out into the field and discovering the world for themselves. Again, he was not alone in this view. By mid-century it was something of a cliché for writers of popular geological works to exhort their readers to put down their novels and turn their eyes to nature. Notwithstanding the fact that he often urged his fellow geologists to learn to write better prose in order to compete in the literary 
marketplace, in 1853 the prolific geological writer and Geological Survey palaeontologist Edward Forbes wrote, in typical vein, that

A man, to be a true geologist, must have a body as well as a soul [...] No mincing town-dandy or sickly bookworm is likely to thrive in the profession. He must put his gloves in his pocket, and turn his hand to the hammer, doff patent-leathers, and wear nails in his boots; set his best foot foremost, and take to the tramp, without squeamishness about mud, wet, or brambles. ${ }^{7}$

The image of the masculine, knightly geologist as an all-action hero who preferred 'mud, wet' and 'brambles' to his armchair and a good book was a key selling-point for the science, eschewing feminine and romantic fictions for medieval romance with its notions of chivalry, truth and honour. Charles Kingsley, author of not only six novels including The Water Babies (1863) but also three works of geology and natural history, lecturer on these topics at Wellington College and the Working Men's College, founder of the Chester Society for Natural Science, and elected member of the Geological Society in 1863, absorbed this rhetoric into the fabric of all his work and thinking. Geology was his 'favourite hobby' since he 'was a boy'; 'writing novels' was 'a farce and a sham'. ${ }^{8}$ He frequently considered never writing another novel, though he just as frequently relented. He told his students not to read novels when they took train journeys, but to look out of their carriage windows and examine the strata revealed in the cuttings. And he defended himself against claims that he was, in his words, 'a 'sentimentalist' and a 'fanatic' on the grounds that his accusers 'little know how thoroughly my own bent is for physical science; how I have been trained in it from earliest boyhood; how I am happier now in classifying a new polype, or solving a geognostic problem of strata, or any other bit of hard Baconian induction, than in writing all the novels in the world'. 9 Though Kingsley was one of the earliest proponents of evolutionary theory (in the form in which it had been imagined by Charles Darwin), he was troubled by Vestiges. Its evolutionary argument and its rhetorical power were attractive to him, but he was also keenly aware of the scientific reaction to its flaws, mistakes and literary form from the geological community of which he aspired to be a part. It was not until 1859, when the gentlemanly Charles Darwin proposed an evolutionary theory in a respectable non-narrative form in Origin of Species, that Kingsley would feel comfortable articulating his own evolutionary views. Even then, the antinarrativistic rhetoric of geological writing continually bedevilled his efforts to write

Adelene Buckland, Losing the plot: the geological anti-narrative 19: Interdisciplinary Studies in the Long Nineteenth Century, 11 (2010) www.19.bbk.ac.uk 
even a more serious, more 'realist' form of fiction. Darwin, we might remember, famously portrayed himself as having lost his aesthetic sense as his life wore on, and to have stopped reading poetry, though he certainly continued reading novels. Novels, it seems, did not rank high enough to require an aesthetic sensibility, and their status in the wider culture is at least in part responsible for what we now see as an anti-literary stance toward the novel in so much description of science and men of science in the nineteenth century. ${ }^{10}$

It would be possible here, as Ralph O'Connor has done, to show a different side of this trend, in which popular geological writers claimed their science was actually superior to 'romance' (and the kind of 'romance' being denigrated differed from text to text) in that it contained all the wonder and imagination of poetry or historical fiction, but was grounded in actual fact. ${ }^{11}$ This is the important flip-side of my argument. But the point remains that the staking out of territory in league or competition with the novel, or in opposition to it, was also endemic in the first half of the century. And this leaves out the second, perhaps more substantial problem, for Sedgwick and others about novels - and especially about cheap, garish, or toothrilling novels with wild and wonderful plots. In elite literary culture, the novel was not only considered as an effeminate and seductive form too avidly consumed by women and the working classes, but it threatened to shape the way the world, and its history, could be imagined. Seeing the history of the earth through the patterns of stories, trying to write the story of earth history before all the evidence had been collected, men and women might be seduced from the arduous task of seeing it as it really was. Bad literary form was an indication of bad scientific thinking.

Sedgwick's repugnance to the novel, and particularly to cheap print forms, was more than mere eccentricity. It was symptomatic of a deep-rooted suspicion of storytelling within the elite literary community to which leading geologists aspired to belong, and of their desire that their science should find a place in literary culture and remove its tainted association with evolutionary and scriptural cosmologies circulating in less reputable portions of the press. The Geological Society of London had been formed in 1807 to salvage a science from the wreckage of Enlightenment 'theories of the earth', theories which had promised to tell the entire story of earth history, but had become associated with atheism, revolution, and damaging scientific controversy. ${ }^{12}$ On the streets, in the clubs, the press, and in the theatres of 
Walter Scott's Edinburgh, the intellectual community had come to blows over two rival 'theories of the earth': the Royal Society had split in two and the Wernerian Natural History Society had been set up to rival it, and Scott himself was brought tangentially into the fray in 1812 when his friend George Steuart Mackenzie had a play Scott had commissioned deliberately and publicly sabotaged by those on the other side of the geological fence. ${ }^{13}$ When Scott had become President of the Royal Society of Edinburgh, which had lost members due to the dispute, he pronounced mockery on the men of science who claimed to know everything about the world's formation and history. Instead, in his inaugural speech he 'got up the well-worn opinion of Mr. Jenkinson in the Vicar of Wakefield upon the Cosmogony of the World'. ${ }^{14}$ The opinion was, pride comes before a fall, and the more prosaic claims to knowledge of an unworldly vicar ultimately trump the con-tricks of the fake cosmogonist Mr. Jenkinson, who knows his own pretensions to be 'absurd'. The gentlemen of the Geological Society, avid Scott readers all, agreed that if there was to be a recognisable scientific discipline called 'geology', they needed a different form than those Enlightenment cosmologies and cosmogonies that had thrown them into such dispute.

It may seem a paradox, but Scott was an important caveat in this antinarrative style for geology, for two reasons. First, he had bartered a new cultural prestige for the novel and especially for the historical novel, a kind of novel which could be associated with masculinity instead of femininity, and geology needed to make the same kind of cultural move. In the Edinburgh Review and the Quarterly Review (the latter of which he had co-founded), Scott's novels were praised for the truth to fact, their masculine honesty, their accurate historical scholarship, in terms which opposed his novels to the genre as a whole. ${ }^{15}$ Scott's fiction was widely considered a form of historical writing, a mode of writing which, though it was still romantic enough to attract interest and captivate the imagination, was antiquarian in detail and method, and which deployed irony in its fictional frames to poke fun at plot as a mode of organising knowledge. He 'could never form a plot', Scott's narrators told his readers, over and over again, preferring episodic and meandering narration, with poorly connected scenes and a lack of control over beginnings and endings. ${ }^{16}$ This rhetorical repudiation of tightly-constructed plot was couched in masculine, ironic, devil-may-care terms. And as the new geologists ventured into the 
wilderness on geological fieldwork, for instance, they often read Scott. They imagined themselves as Waverley heroes questing into unexplored terrain. At their clubs and societies, they played drinking games Scott had created for his fictions, and in public they galvanised support for the Scott monument, which now stands on Princes Street in Edinburgh. What Scott had achieved for the novel, the geologists hoped to achieve for their suspect science. Even Sedgwick liked Scott. ${ }^{17}$

This exception, the fiction of the weighty cultural figure of Scott, as opposed to the cheaper thrills of proliferating forms of other fictions, was rooted in the social circles in which many geologists moved, friends with historians such as Hallam, with politicians, and with their indebtedness to antiquarianism as a mode of historical practice. It gave them a literary style by which to imagine themselves as historians of the earth who were able to step back from narrative and view it ironically or with the necessary rational detachment of the Scott narrator, and to present their imaginative and suspect science in culturally authoritative, but nonetheless popular, terms. Scott's influence cannot be underestimated: the geologist Thomas Dick Lauder, who wrote important early papers on the geological formation of the parallel roads of Glen Roy, a phenomenon which continued to baffle geologists long into the century, also wrote novels in direct imitation of Scott, in which accurate and perhaps even original geological description was the means of evacuating irrational, supernatural explanations from the plot. ${ }^{18}$ The English teacher Charles Lapworth, who chose to accept a post in Galashiels partly because it was Scott country, went on to solve the most vehement debate about the classification of the strata ever fought in geology. He wrote lectures in his subsequent post at Mason College, later the University of Birmingham, filled with quotations from and allusions to Scott, explicitly used as a means of orienting the lecture audience in the landscape, so that the geological analysis of the landscape was in part performed by a descriptive mode familiar through the reading of Scott's fictions. ${ }^{19}$ The forms of Scott's fictions helped geologists manage the problems of plot, to stop their stories of the earth and its history from becoming too speculative and fanciful, or too liable to seduce themselves and their readers.

If 'romance' was one foil against which the serious 'realist' novel, and a modern form for geology, came into being, then 'epic' was certainly another. ${ }^{20}$ Rejecting the cosmogonies and cosmologies of the eighteenth century, geologists 
claimed that their work in the 'infancy' of the new science would be to observe the world accurately and to defer the telling of stories until a far greater body of evidence had been amassed. As they did so, they not only rejected 'romance' but debated the appropriateness of all totalising or too-exciting narrative forms - even those with the highest levels of cultural authority, such as the epic. For some geologists, like William Buckland, Reader of Geology at Oxford, the power of the new science lay in the promise that it might one day provide the story of earth history, that one day the epic of earth history might be written. Buckland was famous for reanimating the habitats of extinct creatures whose remains he explored in caves in Yorkshire and South Wales. Such work did not provide an epic view of the history of the planet but almost its opposite, a synchronic immersion into a single scene of its past, the fossils and landscapes of a single moment in earth history vividly recreated as a compelling picture. ${ }^{21}$ And yet, as O'Connor has shown, in relatively private settings and in ephemeral spaces in his texts - at the ends of his lectures and chapters, for instance, Buckland's ecological reconstruction of particular scenes of deep time gave way to this epic promise. Prehistoric caves and underground caverns became mysterious realms inhabited by latter-day dragons and beasts, and which could only be interpreted by gentlemen geologists conceived of as epic guides and heroes questing into the subterranean depths. Buckland's writings and performances alluded regularly to Homer, Virgil, Dante and Milton, investing geology with perceived compatibility with the textual scholarship of classics and the Bible. At Oxford, of course, where Buckland was a Professor, classics and the Bible formed the backbone of the curriculum. The teleological narrative line of epic, with its claim to describe total history, could give dramatic shape to the history of the earth, so that the geologist-guide could one day, when the science had finally matured, advance 'a cosmic narrative tracing a progression from brute matter to humanity over millions of years' ${ }^{22}$ For now, Buckland contended, geologists could not hope to construct a diachronic or connected narrative of earth history in all its glorious totality. But in the future, who knew where the possibilities might lie. ${ }^{23}$

On the opposite side of the fence was one of Buckland's most promising students, Charles Lyell, now famous for having penned one of the most important works in the history of geology, Principles of Geology (1830-33), who had gone up

Adelene Buckland, Losing the plot: the geological anti-narrative 19: Interdisciplinary Studies in the Long Nineteenth Century, 11 (2010) www.19.bbk.ac.uk 
to Oxford in 1816 hoping to become a poet. He entered the Newdigate Prize at Oxford three years running, and was disappointed each time. Only two of Lyell's poems have been published (though more may exist in the archive at Kinnordy House, his home in Scotland), and both reveal traces of his passion for Byron's poetic innovations. In a poem 'Lines on Staffa', Lyell wrote up geological research he had undertaken for Buckland in his summer vacation through an imitation of the Spenserian stanza, a form Byron had popularized in Childe Harold's Pilgrimage (1812). ${ }^{24}$ When Lyell left Oxford and moved to London, began practising law, and attempted to ingratiate himself in metropolitan literary circles, it was a Byronic form that would increasingly structure his apprehension of the earth, and would cause him directly to challenge Buckland's scientific authority.

Herbert Tucker has recently demonstrated that, in the wake of Byron's achievement in Childe Harold, epic poetry became a heroic impossibility for all but the apocalyptic and deluge poets whose work flooded from the presses in the 1820s and from which geologists would become keen to distance themselves and their science. ${ }^{25}$ Indeed, this resistance to epic as an outmoded order is discernible in a much wider set of cultural debates than the poetic, debates in which Lyell was both onlooker and occasional participant. Attempting to win the hand of his future wife Mary Horner in 1831, he wrote her an account of his life, telling her stories about the precocious young boy-poet he had been before his disappointment with the Oxford prizes, putting special and extended emphasis on his ability with 'mockheroics'. ${ }^{26}$ More publicly, in 1829 Lyell reviewed Gabriele Rossetti's controversial Comento Analitico on Dante's Divine Comedy as a favour to his father, who was good friends with Rossetti. Rossetti had argued that Dante's poem was not an epic in the true sense, but a coded allegory designed to communicate secret anti-papal messages between members of an ancient heretical sect. For Rossetti, epic was a fallible historic document, not a perfect expression of a completed and allencompassing past. $^{27}$

Lyell criticised Rossetti, not wanting to be associated with what was a historical project roundly condemned as absurd. But he praised another antiepicising scholar, Georg Barthold Niebuhr, whose Römische Geschichte had recently been translated into English by friends of Adam Sedgwick and was also causing a furore on the pages of the Quarterly Review in $1829 .{ }^{28}$ Deeply critical of 
classical sources, and especially of the histories of Livy and Dionysus, Niebuhr had said that these authoritative Roman historians had not provided factual records of the Roman people but had brought 'down the marvels of the heroic ages into the sphere of history', writing 'an epical narrative of actions and events' whose true relation to the past had now to be subjected to 'scientific' scrutiny. ${ }^{29}$ Niebuhr largely invented source criticism and, as Rossetti was, he stood charged with an excess of imagination, arrogantly reconstructing Roman history to his own design (itself no less fallible than that of Livy), and of a damaging scepticism about authoritative classical sources. But for Lyell, this chimed with his urbane literary sensibilities and struck him as an appropriate model for the historical reconstruction of geological ages, for which the evidence was obscure and fragmentary. 'He who calls the vanished past back again into being,' he wrote in Principles, citing Niebuhr, 'enjoys a bliss like that of creating, ${ }^{30}$ Geologists, poets, literary critics, novelists like Scott, and historians, all were shedding the traditional and iconic narrative forms of epic in favour of a new, scientific or at least ironic kind of scrutiny of the world and the stories that were told about it. Indeed, the popularity of mock-epic in the eighteenth and early nineteenth centuries has been considered as concomitant with the rise of the novel, both sharing an emphasis on particulars, a mixing of 'high' and 'low' art forms, a struggle to find artistic coherence, and a questioning of traditional forms of literary, political or religious authority. ${ }^{31}$ Lyell's geology shared all these elements, too. In this context, Buckland's epic of earth history, as important as it had been, could be made to look like an apology for the biblical account of the making and unmaking of worlds.

Lyell, no longer a poet but nonetheless a man of yearning literary ambition, re-shaped contemporary visions of the earth in Principles of Geology in line with this urbane new aesthetic. Fossils, he contended, were poorly preserved, the strata only rarely and randomly deposited, and the human ability to observe geological processes, many of which took place at the bottom of the sea or in the depths of the earth's core, was derisory. The earth was subject to ongoing, random, and sporadic violence, which disrupted and destroyed geological evidence. Its beginnings and endings were unknown and unknowable, the shape and pattern of earth history obscure, and the story of that history, rejected at least in principle by his colleagues, would never be known. Though many critics have considered Lyell's 
'uniformitarianism' as a plot of earth history, as James A. Secord has put it, Principles of Geology was an 'anti-narrative', designed to take the resistance to story endemic in the methods and practices of Geological Society geology to its fullest conclusion. ${ }^{32}$ Just to give a few examples, Lyell quoted Samuel Butler's Hudibras with its mockery of Thomas Burnet's cosmological work Sacred Theory of the Earth. ${ }^{33}$ He used Milton and Dante not only to inspire his readers with a sense of the poetic grandeur of geology but in many cases as mere pieces of historical evidence for the geological lay of the land in the periods in which they had been writing. ${ }^{34}$ He mocked his colleagues and predecessors by accusing them of having the same perspective on earth history as Umbriel, the gnome in Pope's mock-epic The Rape of the Lock or of Dante in fourteenth-century Italy. ${ }^{35} \mathrm{He}$ also continued to identify with Byron, counseling his fellow geologists to 'overcome those [...] impressions which induced the poets of old to select the rock as the emblem of firmness - the sea as the image of inconstancy' and to take heed of 'Our modern poet' who, 'in a more philosophical spirit, saw in the latter "The image of Eternity," and has finely contrasted the fleeting existence of the successive empires which have flourished and fallen on the borders of the ocean, with its own unchanged stability', finishing with a quotation from the fourth canto of Childe Harold. ${ }^{36}$ If it was 'the present moment' that was 'Byron's strong suit', as Tucker has written, then it was Lyell's 'strong suit' too, as he used the present as 'the key to the past', making 'a black hole in narrative', 'subordinating opinion, description, and momentum to the advancement of a central self without evident motive, bearing, or goal'. ${ }^{37}$ Lyell's earth was a Byronic hero, thronging and alive with change, change in all directions, at all times, by all possible means. And by implication, Lyell was the Byron of the new geology.

In the current literature, geology has tended to be cast as the handmaiden of evolutionary biology. ${ }^{38}$ Critics working in nineteenth-century literature and science are indebted to the works of Gillian Beer, George Levine, and Sally Shuttleworth for their subtle and perceptive treatments of evolutionary writings as important literary as well as scientific documents. They are equally indebted to Beer for the powerful argument that the 'plots' of Darwin's writing - of the lateral 'tangled bank' relationships between creatures and events over an imperceptibly long span of time - were in part shaped by literary plots and then re-appropriated by them. Novelists

Adelene Buckland, Losing the plot: the geological anti-narrative 19: Interdisciplinary Studies in the Long Nineteenth Century, 11 (2010) www.19.bbk.ac.uk 
including George Eliot, Charles Dickens and Thomas Hardy shaped their fictional worlds by absorbing or contesting the patterns of evolutionary development. ${ }^{39}$ Subsequent critics have adopted this model and applied it to nineteenth-century geology, identifying plots of 'uniformitarianism' (Lyell's gradualistic model of change to which Darwin was indebted) and a violent 'catastrophism'. ${ }^{40}$

But, under historical scrutiny, arguments that may work very well for evolutionary biology do not work nearly so well for geology. I have argued in this essay that plots were problems for geologists, not proofs, and they could hardly be used as uncontroversial frameworks for novelistic stories. Though there is not space to argue this fully here, it should be clear that the arguments between Lyell and the other geologists belonging to his intellectual community could not be boiled down to a simple opposition between his 'uniformitarianism' and their 'catastrophism': neither of these was a distinct school of thought and many geologists agreed with Lyell's ideas, many of which were restatements or agreements with their own. Many, including Adam Sedgwick and the imperial geologist Roderick Murchison, agreed with Lyell that gradual processes could explain large-scale geological change (though, unlike Lyell, they thought that events of a greater intensity than humans had ever witnessed may have operated at other points in geological history). Differences between geologists were subtle and complex, determined much less by religious denomination (as is sometimes asserted) than by forms of publication, institutional affiliations, networks of friendships and collaborations, access to travel and regional differences, and to the exhibitions, museums, lectures, and to the written works these men read and produced. If we are fully to get to grips with the literary dimensions of geological science, as literary critics we must continue to learn from historians of geology in order to unpack the full range of this complexity, and to pay closer scrutiny to the many geological books, lectures, periodical essays, maps, columns and scientific papers geologists produced.

It is not that narratives of earth history were not important to the birth of geology as a culturally-authoritative discipline. Recent work by scholars in history of science, or paying close attention to it, such as that by O'Connor and Secord, continues to emphasise narrative as a central mode by which geological writers garnered support for their work and views, or generated literary 'sensations' by it. ${ }^{41}$ This close attention to the nuances and complexities of the different kinds of 
narrative deployed by different historical actors, for different reasons, in different literary modes, and in the different scientific spaces (the museum, the exhibition, the panorama, the periodical, the lecture hall) which inflected the meaning of 'geology', marks a distinct move forward in the study of geology and literature, and I am thoroughly indebted to this work. I seek to add to it here by arguing that narrative was as often a problem as a possibility for nineteenth-century geologists, that the points at which they avoided narrative is equally telling as the places in which they used it. And I want to take O'Connor's argument for the uses of narrative to geological popularisers a step further: sensitive not only to its uses but also to its abuses, geologists, in line with the historians, poets, critics and novelists who were their friends and colleagues, self-consciously interrogated the epistemological value of different literary forms and structures as modes of apprehending and organising knowledge. Arguments about the form and structure of the earth and its history were always, in part, arguments about literary form and structure, too. Literature was a mode of scientific practice, akin to fieldwork, collecting, and observation: the form a writer gave to earth history, to a novel, to a poem, or to a history, would determine just how authoritative his view could be said to be, just how compelling his vision of the globe would be to his colleagues and to the wider public. And thus, for the very same reason that narrative was a powerful tool for captivating and converting new readers to geology it was also condemned as suspiciously irrational, encouraging those captivated readers to suspend their disbelief, numbing them to the proper forms of rational inquiry. For realist novelists, questing to give the novel a new cultural authority, and for geologists, seeking to do the same for their science, narrative had a much more ambiguous and much more complex role to play than we, with our own narratives of the relations between 'science' and 'literature', have hitherto been accustomed to believe.

\footnotetext{
${ }^{1}$ Adam Sedgwick, Discourse on the Studies of the University of Cambridge (1850), p. clviii.

2 Charles Lyell to Gideon Mantell, March 2 1827, in Life, Letters and Journals of Sir Charles Lyell, ed. by Katharine M. Lyell, 2 vols (London: Murray), I, p. 168.

${ }^{3}$ Michael McKeon, 'Prose Fiction: England', in The Cambridge History of Literary Criticism, Volume Four: The Eighteenth Century, ed. by H.B. Nisbet and Claude Rawson (Cambridge University Press, 1997), p. 240.
}

Adelene Buckland, Losing the plot: the geological anti-narrative 19: Interdisciplinary Studies in the Long Nineteenth Century, 11 (2010) www.19.bbk.ac.uk 
${ }^{4}$ See Michael McKeon, 'Prose Fiction: England', pp. 238-263. See also Michael McKeon, Origins of the English Novel (Baltimore: Johns Hopkins, 1987), chapters 1, 3, 9, 11. On the 'anti-literary thrust' of nineteenth-century realism and its rejection of 'falsifying genres' see, for instance, George Levine, The Realistic Imagination: English Fiction from Frankenstein to Lady Chatterley (University of Chicago Press, 1981), p. 12.

${ }^{5}$ For examples see Sedgwick to Ingle, March 24 1837, in Clark and Hughes, Life and Letters of the Reverend Adam Sedgwick, ed. by John Willis Clark and Thomas KcKenny Hughes, 2 vols (Cambridge University Press 1890), I, p. 481. Sedgwick to Joseph Beete Jukes, November 2 1855, CUL Add. 7652/7650. Box 9, III E.10. Sedgwick to Joseph Beete Jukes, December 15-17 1855, CUL Add. mss. 7652/7650. Box 9, III E.11. Sedgwick to Fanny Hicks, January 3 1847, in Clark and Hughes, Life and letters (1890), II, p. 108.

${ }^{6}$ Adam Sedgwick to Roderick Murchison, c. 1837, in Clark and Hughes, Life and letters (1890), I: 500-01.

${ }^{7}$ [Edward Forbes], Geology, Popular and Artistic, Dublin University Magazine, 42 (1853), pp. 33849 (p. 339).

${ }^{8}$ Charles Kingsley, 'To George Brimley, Esq., Eversley, 1857', in Charles Kingsley: His Letters and Memories of his Life, ed. by Fanny Kingsley, 2 vols (London: King, 1877), II, p. 44.

${ }^{9}$ Charles Kingsley, 'To Thomas Cooper, Torquay 1854', in Fanny Kingsley, Charles Kingsley, I, pp. 379-80 (p. 380).

${ }^{10}$ See 'Darwin's Humane Reading: The An-Aesthetic Man Reconsidered', Victorian Studies 26.1 (1982), 51-63.

${ }^{11}$ See Ralph O'Connor, The Earth on Show: Fossils and the Poetics of Popular Science, 1802-1856 (University of Chicago Press, 2007).

${ }^{12}$ See Roy Porter, The Making of Geology: Earth Science in Britain 1660-1815 (Cambridge University Press, 1977), pp. 203-208; Martin Rudwick, Bursting the Limits of Time: The Reconstruction of Geohistory in the Age of Revolution (University of Chicago Press, 2005), pp. 463469 and Adelene Buckland, Novel Science: Fiction and the Geological Imagination (University of Chicago Press, forthcoming 2012), chapter 1.

${ }^{13}$ Scott, 'To Joanna Baillie, April 4 1812', in Letters of Sir Walter Scott, ed. by Herbert Grierson, 7 vols (London: Constable, 1932-1937), III, p. 101. For another description of this episode, including some excerpts from the play see Wawn, The Vikings and the Victorians: Inventing the Old North in Nineteenth-Century Britain (Cambridge: Brewer, 2000), pp. 48-53 and Wawn, 'Gunnlaugs saga ormstungu and the Theatre Royal Edinburgh 1812', Scandinavica 21 (1982), 139-51. The play is at the Huntington Library, California. Some of these examples of Scott's imbrication in Edinburgh geological debates have also been pointed out, along with several examples of the geological nature of his landscape descriptions, by Dennis R. Dean in Romantic Landscapes: Geology and its Cultural Influence in Britain, 1765-1835 (Scholars and Facsimiles Reprints, 2007), pp. 188-197.

${ }^{14}$ Scott, 'To John B.S. Morritt, 8 December 1820', Letters of Sir Walter Scott, ed. by Herbert Grierson, VII, pp. 307.

Adelene Buckland, Losing the plot: the geological anti-narrative

19: Interdisciplinary Studies in the Long Nineteenth Century, 11 (2010) www.19.bbk.ac.uk 
${ }^{15}$ See Ina Ferris, The Achievement of Literary Authority: Gender, History and the Waverley Novels (Ithaca, NY: Cornell University Press, 1991), chapters 1 and 2. For a discussion of the early Edinburgh Review as 'predicated wholly on reviews written by men about men and for men', though later developing an uneasy acceptance of women's writing, see Curran, 'Women and the Edinburgh Review', in British Romanticism and the Edinburgh Review: Bicentenary Essays, ed. by Duncan Wu and Demata Massimiliano (Basingstoke: Palgrave), pp. 195-208 (p. 198).

${ }^{16}$ For many examples see Scott, Prefaces to the Waverley Novels, ed. by Mark Weinstein (Lincoln: University of Nebraska Press, 1978).

${ }^{17}$ Several of the leading gentlemanly geologists visited Scott at Abbotsford: see William Whewell to Richard Jones, Trinity/Add.Ms.c/51/222 and Archibald Geikie, Life of Roderick Murchison 2 vols (1875), I: 91 and Clark and Hughes, Life and Letters (1890), I: 397-98. For Darwin's enthusiasm for him see Life and Letters of Charles Darwin (1887), I: 40, 125, and Adrian Desmond and James Moore, Darwin's Sacred Cause: Race, Slavery and the Quest for Human Origins (London: Allen Lane, 2009), p. 30. For Sedgwick's enthusiasm see Clark and Hughes, Life and Letters (1890), I: 3 and, for a much greater discussion of his reading of Scott from original sources see Adelene Buckland, Novel Science (2012), chapter 2.

${ }^{18}$ Lochandu: A Tale of the Eighteenth Century, 3 vols (Edinburgh: Constable, 1826) and The Wolfe of Badenoch: A Historical Romance of the Fourteenth Century, 3 vols (Edinburgh: Constable, 1827).

${ }^{19}$ See for example 'Lectures given in Edinburgh. [1878?], in Lapworth museum of geology, University of Birmingham, L28.3c. For his solving of a stratigraphical dispute see James A. Secord, Controversy in Victorian Geology: The Cambrian-Silurian Dispute (Princeton University Press, 1986).

${ }^{20}$ See Georg Lukacs, Theory of the novel: A historico-philosophical essay on the forms of great epic literature, trans. by Anna Bostock (MIT Press, 1971), esp. pp. 56-69; José Ortega y Gasset, Meditations on Quixote (University of Illinois Press, 2000), esp. pp. 118-120; Mikhail Bakhtin, The Dialogic Imagination: Four Essays, ed. by Michael Holquist, trans. by Caryl Emerson and Michael Holquist (University of Texas Press, 1981), pp. 3-41.

${ }^{21}$ On Buckland's cave geology see Nicolaas A. Rupke, The Great Chain of History: William Buckland and the English School of Geology, 1814-1849 (Oxford: Clarendon Press, 1983), pp. 29-95, and particularly the following three works by Marianne Sommer: “'An Amusing Account of a Cave in Wales": William Buckland (1784-1856)', British Journal for the History of Science, 37 (2004), 5374 and 'The Romantic cave? The scientific and poetic quests for subterranean spaces in Britain', Earth Sciences History 22.2 (2003), 172-208, and Bones and Ochre: The Curious Case of the Red Lady of Paviland (Cambridge, MA: Harvard University Press, 2007).

${ }^{22}$ Ralph O'Connor, 'From the Epic of Earth History to the Evolutionary Epic in Nineteenth-Century Britain', Journal of Victorian Culture 14.2 (2009), 207-223 (p. 209).

${ }^{23}$ See Ralph O'Connor, The Earth on Show, esp. chapter 2, pp. 71-116; also O'Connor, 'From the Epic of Earth History', 207-223.

${ }^{24}$ Lyell, in Life, Letters and Journals of Sir Charles Lyell (1881), I, pp. 55-56.

Adelene Buckland, Losing the plot: the geological anti-narrative 19: Interdisciplinary Studies in the Long Nineteenth Century, 11 (2010) www.19.bbk.ac.uk 
${ }^{25}$ Herbert Tucker, Epic: Britain's Heroic Muse 1790-1910 (Oxford University Press, 2008), pp. 234268.

${ }^{26}$ Lyell, in Life, Letters and Journals (1881), I, pp. 24-26.

${ }^{27}$ Rossetti, La Divina Commedia di Danti Alighieri con Comento Analitico di Gabriele Rossetti (London: Murray, 1826-27). For a brief description see Dante: The Critical Heritage, 1314?-1870 ed. by Michael Caesar (London: Routledge, 1989), pp. 501-503. For its supporters see Friederich, 'Dante through the centuries', Comparative Literature 1.1 (1949), $44-54$ (pp. 51-52). [Lyell], 'Rossetti's Dante', Foreign and Quarterly Review (1828), 437. For contemporary reception including reviews see Charles Lyell [snr], The Poems of the Vita Nuovo and Convito, trans. by Charles Lyell (London, 1842), p. xlviii; Arthur Henry Hallam, Remarks on Professor Rossetti's "Disquisizioni sullo spirito antipapale" (London, 1832), p. 58. More positive reviews than these can be found in Oriental Herald and Journal of General Literature across three issues in Jul-Aug 1827 and the Literary Gazette (1826) and (1828).

${ }^{28}$ Porter is the only historian to have paid close attention to this Niebuhrian quotation in 'Charles Lyell and the principles of the history of geology', British Journal of the History of Science 9.2 (1976), 91-103 (pp. 96-97), though it is also discussed briefly by Martin Rudwick in Bursting the Limits of Time, p. 302. On Niebuhr see Michael Ledger-Lomas, Selective Affinities: England and Protestant Germany 1815-1870, (forthcoming), chapter 1; and Norman Vance, 'Niebuhr in England', in British and German Historiography, 1750-1900: Traditions, Perceptions and Transfers, ed. by Benedikt Stuchtey and Peter Wende (Oxford University Press, 2000). The discussion of the translation in the Quarterly prompted Hare to reply in A vindication of Niebuhr's History of Rome: From the Charges of the Quarterly Review (Cambridge: Taylor, 1829).

${ }^{29}$ Georg Barthold Niebuhr, The History of Rome, trans. by Connop Thirlwall and Julius Charles Hare, 2 vols (Cambridge: Taylor), I, pp. 3 and 4-5.

${ }^{30}$ Lyell, Principles of Geology (1830-33), I, p. 84.

${ }^{31}$ Gregory G. Colomb, Designs on truth: the poetics of the Augustan mock-epic (Pennsylvania State University Press, 1992), pp. 3, xlviii.

32 James A. Secord, 'Introduction', in Charles Lyell, Principles of Geology, ed. by James A. Secord, (London: Penguin, 1997), p. xviii.

${ }^{33}$ Lyell, Principles of Geology (1830-33), I, p. 37.

${ }^{34}$ Lyell, Principles of Geology (1830-33), I, p. 184.

${ }^{35}$ Lyell, Principles of Geology (1830), I, pp. 82-83.

${ }^{36}$ Lyell, Principles of Geology (1830), I: p. 530.

${ }^{37}$ Tucker, Epic (2008), pp. 191-192.

${ }^{38}$ For a similar view on the historical rather than literary-critical literature see Martin Rudwick, Bursting the Limits of Time, pp. 1-7 (esp. p. 7).

${ }^{39}$ Gillian Beer, Darwin's Plots: Evolutionary Narrative in Darwin, George Eliot and NineteenthCentury Fiction (London: Routledge \& Kegan Paul, 1983); George Levine, Darwin and the Novelists: Patterns of Science in Victorian Fiction (Cambridge, MA: Harvard University Press, 
1988); Jerome Meckier, Hidden Rivalries in Victorian Fiction: Dickens, Realism, and Revaluation, (Lexington: University Press of Kentucky, 1987); Sally Shuttleworth, George Eliot and NineteenthCentury Science: The Make-Believe of a Beginning (Cambridge University Press, 1984).

40 See, for examples of critics explicitly aligning uniformitarianism with literary realism: Shuttleworth, George Eliot, pp. 52, 81; Jonathan Smith, Fact and Feeling: Baconian Science and the Nineteenth-Century Literary Imagination (London: University of Wisconsin Press, 1994), pp. 257, 121, 120; Beer, Darwin's Plots, p. 181; Jonathan Arac, 'Rhetoric and Realism in Nineteenth-Century Fiction: Hyperbole in The Mill on the Floss', English Literary History, 46 (1979), 673-92 (p. 681); Tess Cosslett, The 'Scientific Movement' and Victorian Literature (Sussex: Harvester, 1982), pp. 4-5 and Jerome Meckier, Hidden Rivalries in Victorian Fiction, esp. pp. 243-76.

${ }^{41}$ O'Connor, The Earth on Show; Secord, Victorian Sensation; and the works of Marianne Sommer cited above. 